\title{
ASPEKTY EKONOMICZNE I SPOŁECZNE WOJEN BAŁKAŃSKICH 1912-1913
}

\author{
MIROSŁAW DYMARSKI
}

\begin{abstract}
Mirosław Dymarski, Aspekty ekonomiczne i społeczne wojen bałkańskich 1912-1913 (The economic and social aspects of the 1912-1913 Balkan Wars).
\end{abstract}

Balcanica Posnaniensia. Acta et studia, XIX, Poznań 2012, Wydawnictwo Instytutu Historii UAM, pp. 221-230, ISBN 978-83-63-047-17-7, ISSN 0239-4278. Polish text with a summary in English.

Mirosław Dymarski, Uniwersytet Wrocławski, Instytut Historyczny, ul. Szewska 49, 50-139 Wrocław, Polska - Poland.

Spośród wielu aspektów wojen bałkańskich 1912-1913, jakie są obszarami studiów historyków, należ zwrócić uwagę na jeszcze jeden, szczególnie uniwersalny ekonomiczno-społeczny. Trzeba odnieść się nie tylko do owych skutków w sensie bezpośrednich następstw wojen, ale również do skutków dalszych - tak w perspektywie nieco bliższej, jak i dalszej.

Narastanie napięć między państwami bałkańskimi a Turcją oraz pomiędzy nimi bezpośrednio - co było widoczne jeszcze przed wybuchem wojen bałkańskich - było procesem równoległym do przygotowań, jakie podjęły Grecja, Bułgaria, Serbia i Czarnogóra w celu realizacji głównego narodowego celu - wyparcia Turcji z Półwyspu Bałkańskiego, zajęcia jej terytoriów i ostatecznego ukształtowania granic państwa. Wydaje się, że naturalny pozostaje ścisły związek między możliwościami ekonomicznymi, społecznymi, mobilizacyjnymi, wojskowymi a celami wojennymi, jakie wyznaczają sobie władze polityczne. Tymczasem w przypadku I wojny bałkańskiej (w konsekwencji również II wojny) ten warunek nie został spełniony lub spełniony był w małym stopniu. Wszystkie, bowiem, państwa ligi bałkańskiej przekraczały - niekiedy zdecydowanie - w swoich wojennych planach realne możliwości ich gospodarek, potencjału ludnościowego, zdolności do ochrony ludności cywilnej oraz ofiar wojny (jeńcy), w tym migracji, jako następstw wojny. Ten rodzaj wojny, który angażuje cały potencjał społeczno-ekonomiczny nie był dotąd (do 1912 r.) znany i dlatego możemy mówić o wyjątkowości wojen bałkańskich, będących preludium do I wojny światowej, konfliktu, który zaangażowanie całych gospodarek w wysi- 
łek wojenny przekształcił $\mathrm{z}$ upływem lat $\mathrm{w}$ wojnę masową, wojnę na wyniszczenie. Wojny bałkańskie 1912-1913 pokazały ówczesnym, oczywiście w dużo w mniejszej skali, jak będą wyglądały „,nowoczesne” konflikty po długim okresie pokoju, jaki nastał w Europie po wojnach napoleońskich, przerwanym jedynie Blitzkrigiem francusko-pruskim 1870/1871. Na taki rodzaj wojny wskazał w swoim dziele polski przedsiębiorca Jan Błoch w 1898 r. stwierdzając, że współczesna technika będzie sprzyjać wojnom na wyniszczenie, a to będzie prowadzić do katastrofy ekonomicznej państw zaangażowanych w konflikty ${ }^{1}$.

Grecja, można powiedzieć, starannie przygotowywała się do I wojny bałkańskiej, zważywszy na wcześniejsze, niespełnione aspiracje polityków ateńskich, poczucie dumy oraz gorycz kompromitacji, jaką była 30-dniowa wojna z Turcją w $1897 \mathrm{r}$. Wówczas to okazało się, iż armia turecka - słaba, źle dowodzona i wyposażona-wciąż jest potęgą, kolosem dla Greków i na żadną samodzielną akcję liczyć oni nie mogą, tym bardziej nieprzygotowaną. Wojna pogłębiła kłopoty finansowe Grecji, która w latach 1879-1890 zadłużyła się na ponad $630 \mathrm{mln}^{\mathrm{drachm}}{ }^{2}$, co stanowiło niemal trzykrotność ówczesnych rocznych wpływów do budżetu. Stan finansów Grecji odzwierciedlał chroniczny deficyt lub bankructwo. Budowa struktur państwa od dziesiątków lat przynosiła ogromne straty, w związku z tym ówczesny rząd premiera Nikolaosa Dragoumisa dokonał w latach 1907-1910 skutecznej reformy finansów publicznych, doprowadzając do powstania nadwyżki budżetowej ok. $35 \mathrm{mln}$ drachm, a w latach 1911-1912 rząd premiera Eleftheriosa Wenizelosa uzyskał aż $60 \mathrm{mln}$ drachm nadwyżki. Był to jedyny okres w dwusetletniej historii tego państwa, kiedy rząd dysponował rezerwami finansowymi w budżecie. W momencie wybuchu I wojny bałkańskiej Grecja dysponowała łącznie depozytem gotówkowym wynoszącym $77 \mathrm{mln}$ drachm ${ }^{3}$, co oczywiście nie oznaczało spłaty wieloletnich długów. Niewątpliwym celem tych kroków były przyszłe koszty wojny z Turcją z czego premier Wenizelos zdawał sobie doskonale sprawę. Jednak generalnie finanse Grecji były w opłakanym stanie. Według stanu z 1 stycznia 1913 r., a więc uwzględniwszy już koszty I wojny bałkańskiej - choć nie wszystkie, jako że oblężenie twierdzy Janina nadal trwało - zadłużenie Grecji liczone we frankach wynosiło już prawie 1 mld franków ${ }^{4}$. Jej zobowiązania kredytowe były zatem ogromne, a w konsekwencji wydatków wojennych roczne koszty obsługi długów wzrosły dwukrotnie.

Królestwo Serbii również dogłębnie przygotowywało się do wojny z Turcją zabiegając o kredyty. Jednak kraj był już - podobnie jak Grecja - znacznie zadłużony, starając się wypełniać wszystkie funkcje państwa i jego zadania. I tak od 1862 do 1913 roku Serbia zaciągnęła łącznie 33 kredyty zagraniczne i wewnętrzne, w mo-

1 Por. C. Bartlett, Konflikt globalny. Międzynarodowa rywalizacja wielkich mocarstw w latach 1880-1990, Wrocław 1997, s. 99.

2 J. Bonarek, T. Czekalski, S. Sprawski, S. Turlej, Historia Grecji, Kraków 2005, s. 516.

${ }^{3}$ D. Dakin, Unification of Greece 1770-1923, London 1972, s. 188.

${ }^{4}$ The Other Balkan Wars. Report of the International Commission To Inquqire into the Causes and Conduct of the Balkan Wars, Carnegie Endowment for International Peace, Washington D.C. 1914, s. 262. 
mencie wybuchu I wojny bałkańskiej pozostawało jej do spłacenia 10 kredytów na niebagatelną sumę 815,3 mln dinarów w złocie! Jednocześnie wraz z wojną i wzrostem wydatków załamały się przychody z podatków. Wpływy miesięczne z podatków wynosiły w październiku 1911 r. 5,8 mln dinarów, gdy w tym samym miesiącu roku 1912 wyniosły zaledwie ok. 600 000, by podnieść się w październiku 1913 r. do sumy 2,9 mln dinarów, a zatem połowy kwoty przedwojennej5. Ponadto wojna spowodowała drastyczny wzrost wydatków i obciążeń kredytowych, którym budżet Serbii nie mógł sprostać, doprowadzając w przeddzień I wojny światowej do dalszego pogorszenia się sytuacji finansowej kraju. Zakładane, więc, zwycięstwo Serbii musiało być z założenia pyrrusowe.

Bułgaria - te Prusy Bałkanów - również była w trudnej sytuacji finansowej. W latach 1888-1909 wynegocjowała 8 pożyczek na rozwój infrastruktury, ale zaledwie 1/3 poszła na rozbudowę kolei, reszta poszła na spłatę poprzednich kredytów i wydatki wojskowe ${ }^{6}$. Wiosną 1912 r. premier bułgarski Ivan Geszow wynegocjował od Francji pożyczkę w wysokości 160-180 mln franków, oficjalnie na potrzeby budowy kolei, ale faktycznie na wydatki wojskowe. Całościowe zadłużenie Bułgarii, wyliczone na podstawie dokumentów dostarczonych Komisji Międzynarodowej przez jej władze wynosiło 1083289791 franków! ${ }^{7}$ Bułgaria stawiała więc wszystko na jedną kartę, by osiągnąć narodowe cele, spełnić sen o przyłączeniu Macedonii i Tracji. Charakterystyczne, nie tylko dla Bułgarii, ale dla wszystkich państw bałkańskich było to, że modernizacja polityczna daleko wyprzedzała modernizacje ekonomiczno-społeczną, stąd wyraźny dysonans pomiędzy aspiracjami i dążeniami politycznymi a poziomem rozwoju ekonomicznego, który mógłby tym celom służyć.

Także maleńka Czarnogóra, realizując ambicje dynastii Petrović i osobiste króla Mikołaja I, poniosła ogromne wydatki na wojnę. Od początku XX wieku Czarnogóra przeżywała kryzys w rolnictwie oraz w konsekwencji kryzys żywnościowy. Liczba małego inwentarza (owiec, świń, kóz) nieznacznie rosła do wybuchu I wojny bałkańskiej, gdy liczba bydła znacząco spadła. Nie wystarczało żywności (zbóż) na wyżywienie ludności, gdyż zbiory były niedostateczne. Czarnogóra miała ujemny bilans handlowy. Import wynosił trzykrotność eksportu. Zadłużenie kraju było poważne. Dane ujawniane przez Ministerstwo Finansów Królestwa Czarnogóry były skape, ale w roku 1906 Czarnogóra miała tylko w bankach austriackich 1,5 mln koron zadłużenia, gdy roczne wpływy do budżetu wynosiły $2 \mathrm{mln}$. Ponadto była ona również zadłużona w bankach tureckich (trzy pożyczki w latach 1895-1898), oraz w bankach włoskich $^{8}$. Wszystko to powodowało silną emigrację zarobkową z kraju, głównie do USA i Serbii ${ }^{9}$. Ponadto Mikołaj I wydał na uroczystości związane z proklamacją królestwa w roku 1910 ok. 150000 koron austriackich, co stanowiło więcej niż roczne wydatki

\footnotetext{
${ }^{5}$ Ibidem, s. 260.

${ }^{6}$ J.D. Bell, Peasants i Power. Aleksander Stambolijski and The Bulgarian Agrarian National Union 1899-1923, Princeton 1977, s. 11.

7 The Other Balkan Wars, s. 262.

8 Š. Rastoder, The History of Montenegro, Podgorice 2006, s.127.

${ }^{9}$ Ibidem, s. 133-134.
} 
na edukację w Czarnogórze. Nawet jego zięć, Wiktor Emanuel III, uważał, że uroczystości były ekstrawaganckie i kosztowne. Chcąc podreperować swój budżet Mikołaj I ponownie wystapił do Rosji o subsydia na cele wojskowe 600000 rubli $^{10}$.

Trzeba również nadmienić o sytuacji Turcji. Jako kolos miała ona nieporównanie większe możliwości ekonomiczne niż państwa bałkańskie, jednak jej sytuacja budżetowa wyglądała źle. W roku 1911 inflacja wynosiła aż 300\%, wprawdzie wpływy do budżetu znacząco wzrosły, ale wydatki jeszcze bardziej. W roku budżetowym 1910/11 wpływy wyniosły 2878303 kuruşy, a wydatki 3374511 kuruşy ${ }^{11}$. Wojna włosko-turecka w Trypolitanii również zwiększyła wydatki państwa, tak więc przed wybuchem I wojny bałkańskiej Turcja była finansowo i gospodarczo wyczerpana.

Analizując ogólnie sytuację ekonomiczną państw bałkańskich raport międzynarodowej komisji ds. przebiegu wojen 1912-1913 stwierdzał, że wszelka działalność społeczeństwa w tych krajach skierowana była na wojnę ${ }^{12}$. Ponieważ skala mobilizacji sił, powodowana dążeniem do rozstrzygnięcia ostatecznego, była ogromna, transport w krajach walczących w całości został skierowany na potrzeby przewozu wojsk, artylerii, amunicji, materiałów wojskowych. Fabryki z powodu mobilizacji robotników nagle zaprzestały produkcji, gdyż w tych tradycyjnych, rolniczych społeczeństwach nie istniały możliwości szybkiego zastapienia mężczyzn przez kobiety w warsztatach fabrycznych, rzemiośle, handlu itp. Wraz z odejściem mężczyzn na front, niemal ustała cywilna działalność gospodarcza, a wraz z tym załamały się wpływy z podatków, które były potrzebne rządom państw bałkańskich na pokrycie wydatków wojennych ${ }^{13}$. Koło się zamykało. Gospodarce nie sprzyjało również opustoszenie kont bankowych z oszczędności, jakie zabrali ze sobą oficerowie i żołnierze idący na front. Możliwości kredytowania działalności gospodarczej zostały poważnie ograniczone - w obiegu nie było gotówki.

\section{Mobilizacja}

Wojny bałkańskie były bodaj największą w historii mobilizacjążołnierzy w porównaniu do skali możliwości ludnościowych kraju. Grecja, licząca w 1912 r. 2632000 mieszkańców zmobilizowała 210000 żołnierzy, Serbia zmobilizowała 467630 mężczyzn na łączną liczbę 2945950 mieszkańców, Bułgaria 620567 mężczyzn na liczbę mieszkańców wynoszącą $4329108^{14}$. Najmniej dokładne dane dotyczą Czarnogóry, gdyż znaczna liczba mężczyzn w wieku wojskowym (ok. 13500) przebywała na emigracji zarobkowej. Łącznie jednak na ok. 320000 mieszkańców armia czarnogórska

10 E. Roberts, Realm of the Black Mountain. A History of Montenegro, s. 277-278.

11 S.J. Shaw, E.K. Shaw, History of Ottoman Empire and Modern Turkey, vol. II Reform, Revolution and Republic: The Rise of Modern Turkey 1808-1975, Cambridge 2002, s. 286.

12 The Other Balkan Wars, s. 233.

13 Ibidem, s. 259-260.

14 Ibidem, s. 259. 
zmobilizowała $35600^{15}$ (niektóre źródła podają liczbę 31 000) mężczyzn. Oczywiście nie wszyscy mężczyźni poszli na front, jako że były również ograniczenia sprzętowe. Można jedynie domniemywać, że państwa bałkańskie raczej spodziewały się długiej i krwawej wojny, stąd uruchomione rezerwy.

Należy jeszcze wspomnieć o wysiłku Turcji, chociaż jej możliwości było dużo większe, zważywszy na wszystkie składowe Imperium Osmańskiego. Otóż Turcja zmobilizowała 300 000-320 000 żołnierzy (115000 w Tracji i 175000 w Macedonii ${ }^{16}$ ), liczbę ich później starano się uzupełniać przerzucaniem wojsk z Azji.

\section{Gospodarcze następstwa wojny}

Słabość ekonomiczna tych krajów spowodowała, że w momencie mobilizacji ogromnej liczby mężczyzn los pozostałej ludności: kobiet, starców i dzieci, stał się dramatyczny i zarówno rodziny robotników, rzemieślników, drobnych wytwórców, jak i rodziny chłopskie zostały zepchnięte niekiedy do poziomu głodu. Państwo nie mogło zapewnić choćby minimalnej opieki rodzinom żołnierzy wysłanych na front, a nieliczne organizacje charytatywne nie były w stanie chociażby nakarmić wszystkich potrzebujących. Zresztą potrzeby mobilizacyjne wojska wyssały z rynku nadwyżki żywności, a żadna armia w obawie przed buntem nie pośle w bój głodnego żołnierza ${ }^{17}$. Dodatkową przyczyną głodu był paraliż handlu z powodu zajęcia całego transportu na potrzeby wojska ${ }^{18}$. Przyczyniło się to również do dewastacji środków transportu, co odbiło się później na procesie odbudowy gospodarczej tych państw. Dla przykładu koleje bułgarskie straciły na braku przewozów komercyjnych $30 \mathrm{mln}$ franków, a musiały wydać na dodatkowe zakupy oraz naprawy taboru około 23 mln franków ${ }^{19}$.

Jedynie Grecja nie odczuła tak dotkliwie skutków ekonomicznych wojny, gdyż ze względu na liczną diasporę na całym świecie transfery pieniężne od emigrantów do rodzin w kraju znacznie łagodziły następstwa gospodarcze wojny. Ale to odnosiło się jedynie do Grecji.

\section{Straty wśród żołnierzy}

Wojny bałkańskie należały do bardzo krwawych i niszczycielskich. W ich wyniku Bułgaria straciła 579 oficerów, 44313 żołnierzy zabitych w walce, 71 oficerów i 7753 żołnierzy uznano za zaginionych. Liczba rannych była wprost zdumiewająca:

15 Š. Rastoder, op. cit., s. 139.

16 R. C. Hall, The Balkan Wars 1912-1913. Preludu to the First World War, London-New York 2002, s. 22.

17 The Other Balkan Wars, s. 246-247.

18 Ibidem, s. 247-250.

${ }^{19}$ The Other Balkan Wars, s. 250. 
1731 oficerów i 102853 żołnierzy. Liczba rannych, którzy zostali na trwałe inwalidami była na tyle znacząca, że Bułgaria uruchomiła w Sofii wytwórnię protez dla żołnierzy, którym amputowano nogi.

Serbia straciła 22000 zabitych i 25000 rannych; były to dane publikowane przez źródła serbskie. Inne źródła wskazywały dużo mniejszą liczbę zabitych - 16 500, ale aż 48000 rannych. Ponadto 45000 żołnierzy serbskich zachorowało, głównie na cholerę; chorowali na nią nie tylko Serbowie, ale żołnierze wszystkich armii. Dane ostateczne przedstawione Skupsztynie w 1914 r. mówiły o 12-13 tys., zabitych, od 17800 do 18000 zmarkych w wyniku ran, cholery i innych chorób oraz 48000 rannych $^{20}$.

Czarnogóra natomiast poniosła, relatywnie do wielkości swej armii, największe straty. Spośród 35600 zmobilizowanych, zabitych zostało 2430 żołnierzy, 406 zmarło w wyniku ran i chorób, a 6603 żołnierzy było rannych, co daje łącznie liczbę 9439 , blisko 1/3 stanu czarnogórskiej armii! ${ }^{21}$.

\section{Uchodźcy}

Najbardziej spektakularnym i tragicznym, ale również najbardziej długotrwałym skutkiem I i II wojny bałkańskiej były fale uchodźców. Ucieczki, ewakuacje, emigracje, przesiedlenia to zjawiska, które rozpoczęły się w październiku 1912 r., ale trwały jeszcze kilkanaście lat, jako dalekosiężne następstwa obu wojen oraz w dalszej konsekwencji także wojny turecko-greckiej z lat 1921-1922. Nie ma ona bezpośredniego związku z wojnami bałkańskimi, ale pośrednio się z nimi łączy.

Żądza odwetu wśród narodów bałkańskich była wielka i początek konfliktu był zapowiedzią gwałtów na ludności muzułmańskiej, nie tylko tureckiej, ale również albańskiej, bośniackiej, na bułgarskich Pomakach. Wraz z postępami armii serbskiej, greckiej, bułgarskiej i wycofywaniem się sił tureckich rozpoczął się prawdziwy exodus ludności muzułmańskiej, ale także bułgarskiej i greckiej z terenów zajmowanych przez armie sprzymierzone. W rękach Greków znalazło się ok. 157 tys. uchodźców muzułmańskich, którzy nie zdołali uciec z Macedonii i znaleźli się w okolicach Salonik. Ludność ta otrzymywała bardzo ograniczoną pomoc ze strony władz greckich i organizacji charytatywnych. Zanim jednak udzielono im ograniczonej pomocy, wcześniej przesłuchano niemal wszystkich uchodźców, czy nie są winni zbrodni na ludności chrześcijańskiej.

Od sierpnia 1913 r. rozpoczęły się transporty tej ludności z portu w Salonikach do Anatolii. Inne kraje nie przyjmowały uchodźców, raczej zadowalały się ich masową ucieczką. Same miały, bowiem, problemy z uchodźcami rodzimymi. Od początku walk z Macedonii do Bułgarii uciekło ok. 14-15000. ludzi o poczuciu bułgarskiej tożsamości. Rząd bułgarski szacował, że podczas I wojny bałkańskiej uciekło

\footnotetext{
20 Ibidem, s. 243.

21 N. Andžić, Stvaranje i razvoj crnogorske nacije, Cetinje 1995, s. 217.
} 
do Bułgarii ze wszystkich regionów łącznie 35-40 tysięcy ludzi ${ }^{22}$. W wyniku II wojny bałkańskiej Bułgaria przyjęła jeszcze 30000 uciekinierów z Tracji Wschodniej odbitej przez armię turecką latem 1913 r. i dodatkowo uciekinierów z Dobrudży, zajętej przez Rumunię. Łącznie Bułgaria przyjęła 100000 osób, którym mogła zaoferować jedynie mało gościnne ziemie Tracji Zachodniej ${ }^{23}$.

Grecja przyjęła 20000 uchodźców z Tracji Wschodniej, których osiedliła w Macedonii i przyznanej jej części Tracji Zachodniej.

Oczywiście najbardziej dotkliwe cierpienia spadły na ludność muzułmańską. Łącznie na terenach objętych działaniami wojennymi zamieszkiwało $2315000 \mathrm{mu}-$ zułmanów. Po zakończeniu działań pozostało ich na tym obszarze 1445 000. Łącznie w Anatolii i Tracji zostało osiedlonych 414000 ludności muzułmańskiej z Półwyspu Bałkańskiego w latach 1912-1920, (oraz 398000 w latach 1921-1926, z tego główna część, jako efekt porozumienia o wymianie ludności między Grecją a Turcją). Według szacunków rządu tureckiego w wyniku dwu wojen bałkańskich, z powodu walk, ran, chorób, głodu, represji, mrozu i prześladowania jeńców łącznie śmierć poniosło 632000 muzułmanów, wliczając w to zmarłych jeńców wojennych ${ }^{24}$.

\section{Rabunki}

Jednym z najpowszechniejszych zjawisk obu wojen bałkańskich były rabunki dokonywane niekiedy na masową skalę. Prócz ograbiania domów przeważnie ludności muzułmańskiej, która uciekała przez wojskami sojuszniczymi, rabowano również dobytek Bułgarów, Greków, Serbów Albańczyków. Jednak przede wszystkim ofiarami masowych rabunków była ludność muzułmańska. Ograbiano zagrody i domostwa ze wszystkiego, co miało jakąkolwiek wartość. Rabowano lub konfiskowano zwierzęta i zboże - było po zbiorach. Czyniły to wszystkie strony konfliktu. Nie należy się temu zbytnio dziwić - co nie oznacza akceptować - bowiem mówimy o regionie i terenach często permanentnej biedy. Trzeba jednak wskazać na rabunki dokonywane metodycznie, z użyciem wojska. Nie sposób udokumentować i potwierdzić wszystkie tego typu zdarzenia, ale należy odwołać się do tych, które mają niewątpliwe potwierdzenie źródłowe. Według informacji przedstawicieli Włoch i Wielkiej Brytanii, armia serbska, wkraczająca na tereny Albańczyków na pograniczu dzisiejszej Macedonii i Albanii, zagarnęła ok. 700000 owiec, które uprowadziła do Serbii. Uprowadzanie inwentarza było praktyką wszystkich armii, szczególnie wyspecjalizowała się w tym armia serbska. Grabież bydła była tym dotkliwsza, że poza bezpośrednią stratą były także pośrednie, równie dotkliwe w następstwach. Bydło, bowiem, było na Bałkanach

\footnotetext{
22 J. McCarthy, The Ottoman peoples and the end of Empire, London 2001, s. 93.

${ }^{23}$ J. McCarthy, Death and exile. The Ethnic Cleansing of Ottoman Muslims 1821-1922, Princeton, 1995, s. 155.

${ }^{24}$ J. McCarthy, The Ottoman Peoples..., s. 92.
} 
również siłą pociagową. Tam, gdzie ludność cywilna przetrwała i zachowała swoje zapasy na zasiewy, nie było zwierząt do prowadzenia prac polowych.

\section{Wydatki bezpośrednio na I wojnę bałkańską}

Bułgaria poniosła wydatki 1312654448 franków, w tym wydatki na armię 824782012, wydatki na renty i utrzymanie jeńców - 487863436 franków.

Serbia zaangażowała środki w wysokości 590815500 franków, z tego na armię 574815500 franków, a na jeńców 16000000 franków.

Grecja wydała 467158014 franków, w tym na armię i flotę 393175 014, na renty 54000000 i na jeńców 20000000 .

Czarnogóra wydała łącznie 103000000 franków, w tym na utrzymanie jeńców 2500000 franków ${ }^{25}$.

Według komisji międzynarodowej wszystkie kraje bałkańskie w swoich raportach powojennych zawyżyły wydatki poniesione na wojnę, aby móc domagać się na konferencji pokojowej większego odszkodowania od Turcji. Później niektóre kraje zmniejszyły te wskaźniki, tym niemniej straty i wydatki, jako skutek wojny, były ogromne.

\section{Społeczne i moralne skutki wojen bałkańskich}

Innym aspektem społecznym obu wojen, jest niemierzalna demoralizacja młodych ludzi - żołnierzy przez okrucieństwa wojny, jakich dopuszczały się wszystkie armie walczące. W mniejszym stopniu odnosiło się to do armii tureckiej, która dopiero w II wojnie bałkańskiej, opanowawszy ponownie ziemie Tracji Wschodniej wypędziła stamtąd ludność bułgarską i grecką. Nie mając podstaw do niezbitego dowodzenia, spróbujmy wyprowadzić chociaż jakieś hipotezy w tym względzie. Wojny bałkańskie nastapiły po okresie dość długiego, względnego pokoju. Pozycja Turcji i jej słabość militarna powodowała, że de facto nie podejmowała ona ryzyka wojny przeciwko państwom bałkańskim, zatem starcie z nią nie mogło być postrzegane jak odpowiedź na represje tureckie. Okrucieństwa tureckie, ten rodzaj atawistycznego doświadczenia wielu pokoleń ludów bałkańskich w poprzednich wiekach, nie był znany pokoleniu współczesnemu. Dla przykładu Czarnogóra cieszyła się pokojem od 1878 r., do 1912. Turcja przestała być zmorą dla Czarnogórców, synonimem niewoli i nieszczęścia Czarnogórców. Od 1878 r. od Kongresu Berlińskiego, kiedy Turcja uznała ostatecznie niepodległość Czarnogóry, do 1912 r. upłynęły 34 lata i co najmniej 1,5 pokolenia mieszkańców tego kraju wychowało się w pokoju, żyło bez wojny nie tylko z Turcją, ale z kimkolwiek. To, co ukształtowało typ Czarnogórca - nie-

${ }^{25}$ The Others Balkan Wars, s. 260. 
złomnego wolnego człowieka - walka z Turkiem, odwiecznym wrogiem, w ostatnich dekadach XIX i początkach XX wieku było obce nowym pokoleniom. Mało tego, król Mikołaj I odbył w międzyczasie dwie podróże do Stambułu, gdzie był przyjmowany przez sułtana Abdul Hamida II z honorami. Z jakim zatem doświadczeniem wchodzili do wojny przeciwko Turcji żołnierze czarnogórscy? We wspomnieniach wojewody Simo Popovicia zachował się fragment jego rozmowy z królem Mikołajem I z okresu kryzysu bośniackiego 1908 roku. Gdy groźba ogólnej wojny wisiała w powietrzu Mikołaj powiedział, że nie chce wojny, boi się jej. Był zadowolony z osiagniętych rezultatów i nie pragnął nowego konfliktu. Mało tego, stwierdził, że Czarnogórcy zatracili wolę i zapał do wojny, gdyż tyle wycierpieli, że wojny nie chcą ${ }^{26}$. Również Serbia zaznała pokoju po kongresie berlińskim, nie licząc dość gwałtownej, ale krótkiej wojny z Bułgarią w $1885 \mathrm{r}$.

Okrucieństwa, rabunki, palenie domów, brak poszanowania dla pobitych żołnierzy „zainfekowało” nowe pokolenie mieszkańców Bałkanów niepohamowanym okrucieństwem. Ucieczki, przesiedlenia, czystki etniczne utrwaliły jedynie stan poczucia przegranej, tymczasowości, niespełnionych nadziei i oczekiwania na kolejną okazję do ich spełnienia.

\section{Podsumowanie}

Konsekwencje ekonomiczne i społeczne wojen bałkańskich, jak już wspomniano, miały swoje dalekosiężne następstwa. Kraje bałkańskie odniosły pyrrusowe zwycięstwa lub po prostu porażki, patrząc z perspektywy późniejszych, nieodległych lat. Bułgaria, mimo ogromnych kosztów I i II wojny bałkańskiej, postanowiła w roku 1915 jeszcze raz zaryzykować i zrealizować swój sen o Macedonii. Stanęła po stronie państw centralnych, co w konsekwencji ich przegranej, ściągnęło na Bułgarię - oprócz poniesionych kolejnych kosztów wojny - konieczność spłaty ogromnych reparacji sięgających 2250000000 franków w złocie. Serbia, choć znalazła się w obozie zwycięskich państw Ententy, wcześniej doświadczyła skutków okupacji austriackiej i bułgarskiej oraz skutków ewakuacji setek tysięcy ludzi w wielkim marszu armii, rządu, ministerstw, archiwów i ogromnej rzeszy cywilów, zimą 1915-1916 r. Morderczego marszu przez ośnieżone góry Albanii do portu Duress nie wytrzymało ok. 150000 ludzi. Czarnogóra na tyle osłabła w wyniku I wojny bałkańskiej, iż królowi Mikołajowi nie udało się obronić nie tylko tronu, ale i państwa. W wyniku okupacji austriackiej państwo czarnogórskie właściwie ,abdykowało”, a w roku 1918 zostało wchłonięte przez Serbię, Czarnogóra roztopiła się Królestwie Serbów Chorwatów i Słoweńców nie zachowując nawet żadnego symbolu swej odrębności terytorialnej. Grecja, która podobnie jak Serbia doświadczyła okupacji bułgarskiej, wdała się latach 1921-1922 w wojnę z Turcją, którą przegrała i musiała przyjać na swe terytorium ok. 1,3 mln

\footnotetext{
${ }^{26}$ S. Popović, Memoari, Podgorica-Cetinje 1995, s. 539-540.
} 
uchodźców greckich z Anatolii, doprowadzając do ogromnego kryzysu humanitarnego i permanentnego ubóstwa kraju. Turcja zaś przestała istnieć jako imperium, straciła ogromne terytoria, upadł sułtanat, na co złożyła się przede wszystkim przegrana w I wojnie światowej, ale bez owego preludium, jakim były wojny bałkańskie, jej porażka nie byłaby tak dotkliwa w skutkach.

\title{
THE ECOMOMIC AND SOCIAL ASPECTS OF THE 1912-1913 BALKAN WARS
}

\begin{abstract}
Summary
At the dawn of the XXth century the Balkan countries were intent on waging war against Turkey. In the preparation period, however, they had severely exceeded their economic and demographic capabilities. The arms production consumed vast amounts of money, leading to an extraordinary debt of the Balkan states. The 1912-1913 wars have proved to be a veritable ordeal for the economies of the involved countries as well as their social endurance. This great sacrifice was supposed to further the national goal of defeating Turkey and finally establishing the inter-state borders, even in the face of an impending economic collapse. The Balkan conflicts turned into a war of attrition, a harbinger of what was to come during the World War I. The pre-war efforts and the cost of the actual warfare brought Bulgaria, Greece, Serbia, Montenegro as well as Turkey to the brink of economical breakdown and major social turbulence. The calling of 1.3 million men to arms resulted in halting the industrial production and an agricultural crisis in the countries of the Balkan Alliance. The civilian transport sector was non-existent (since all the means and assets had been requisitioned by the military) which proved fatal to the commerce. This in turn greatly diminished the states' tax income, further worsening the financial repercussions of the war. The number of soldiers fallen, wounded or killed by cholera were reaching hundreds of thousands. Due to the harsh war conditions and the lack of suitable attention many of the wounded have become disabled, which banned them from the work market and doomed them to social benefits. Amongst the consequences of the war were also migrations of the civilians, forced by the war itself and the following border changes. The Christian refugees alone numbered hundreds of thousands, while any real means of administering to the basic needs of the displaced masses were actually non-existent. On the Muslim side the losses amounted to 620,000 Turkish soldiers and civilians. A further 440,000 have been displaced and moved to Anatolia. Moreover the pillage, the atrocity, as well as the destruction of private property have engraved the feelings of mutual hatred and longing for a vendetta in the minds of the Balkan people.
\end{abstract}

